\title{
Two Cases of Injuries with Porcupine Quill
}

\author{
İrfan Aydın', Hasan Övünç Apaydın², Mehmet Akif Dokuzoğlu', Özlem Güler', İbrahim Tunç' \\ 'Department of Emergency Medicine, Adıyaman University Training and Research Hospital, Adıyaman, Turkey \\ 2Department of Pediatric Surgery, Adıyaman University Training and Research Hospital, Adıyaman, Turkey
}

Cite this article as: Aydın I, Apaydın HÖ, Dokuzoğlu MA, Güler Ö, Tunç I. Two Cases of Injuries with Porcupine Quill. J Emerg Med Case Rep 2017; 8: 49-51.

\begin{abstract}
Introduction: Injury is a common reason for admission to the emergency department, but injuries which are caused by a part of a wild animal are extremely rare. Porcupinesare rodents that live in Asia, Africa, and Mediterranean countries, as well as inthe Mediterranean and South East Anatolian regionsof Turkey. Although there are many injuries reported in animals, only a small number of injuries have been reported for humans in the literature.

Case Report: We report two cases of porcupine quill injuries. One case is a 17 year old boy and the other is a 5 year old girl. The quill was approximately in $3 \mathrm{~cm}$ deep at the dorsum of the foot in the physical examination of the boy. In the second case, while she was playing with porcupine quill, it penetrated the periumblical area of her abdomen when she fell on it.

Conclusion: Porcupine quill spikes cause serious penetrating injury in areas where humans live and hunt. Therefore, porcupine arrows should be considered as cutting tools, and thus should be stored in a protected place. Porcupine arrows in a random environment may cause dangerous injury which is presented in our study.
\end{abstract}

Keywords: Porcupine quill, porcupine spike, injury

Received: 28.07.2016 Accepted: 05.10.2016 Available Online Date: 30.11.2016

\section{Introduction}

Porcupines are rodents, and their body is covered with hard bristles. Porcupines live in Asia, Africa, and Mediterranean countries, as well as in the Mediterranean and South East Anatolian regions of Turkey (1). Although there are many injuries reported in animals, only a small number of injuries have been reported for humans in the literature (2). Very few cases were found about human injury $(3,4)$. In this paper we report two cases of porcupine quill injuries in humans.

\section{Case Reports}

Case 1: A 17 year-old male patient was admitted to our emergency department after a porcupine attack. A quill pricked on his foot while he was walking on land (Figure 1). The quill was approximately in $3 \mathrm{~cm}$ deep at the dorsum of the foot in the physical examination. We removed the quill. Dressing and tetanus vaccine was performed. Cephalexin was prescribed orally $1 \mathrm{~g}$ twice/ day and the patient discharged. No complication occurred in the follow-up.

Case 2: A 5 year-old girl was brought to the emergency department by her parents. While she was playing with a porcupine quill, it penetrated the periumblical area of her abdomen when she fell on it (Figure 2). Her general condition was moderate and she was conscious. Her blood pressure was $110 / 70 \mathrm{mmHg}$ and pulse rate was $115 / \mathrm{min}$. Hemogram and other biochemical parameters were in the normal range. Abdominal contrast Computed Tomography (CT) indicated that a foreign body penetrated the stomach. The patient underwent emergency surgery. The surgeon reported that the porcupine quill had penetrated the anterior and posterior gastric wall, and also caused a capsule defect on the second segment of liver (Figure 3). The defects were repaired successfully and a drain was left in the abdomen. The patient was treated with ampicillin intravenously (IV) 400 mg

This study was presented at the $1^{\text {st }}$ Intercontinental Emergency Medicine Congress, 15-18 May 2014, Antalya, Turkey

Address for Correspondence:

Irfan Aydın, Department of Emergency Medicine, Adıyaman University Training and Research Hospital, Adıyaman, Turkey

E-mail: irfanaydinyyu@yahoo.com.tr

oCopyright 2017 by Emergency Physicians Association of Turkey - Available online at www.jemcr.org 


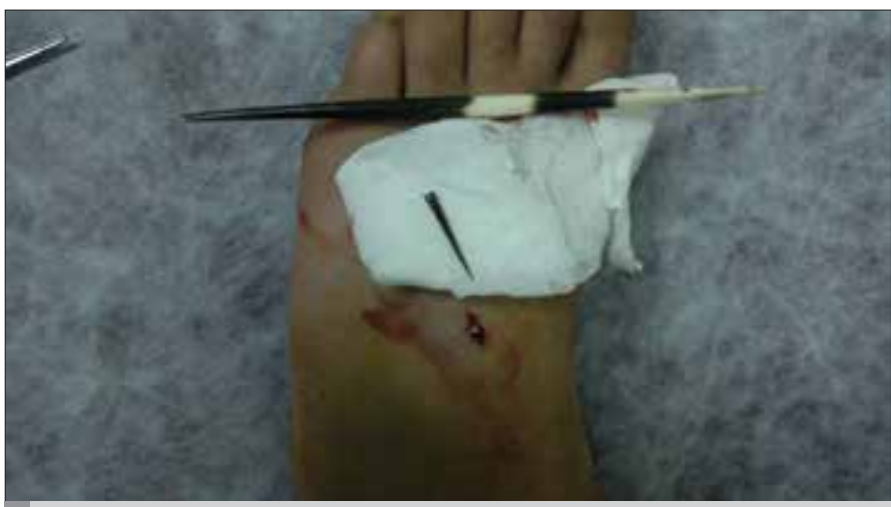

FIGURE 1. Quill on the foot of the first case

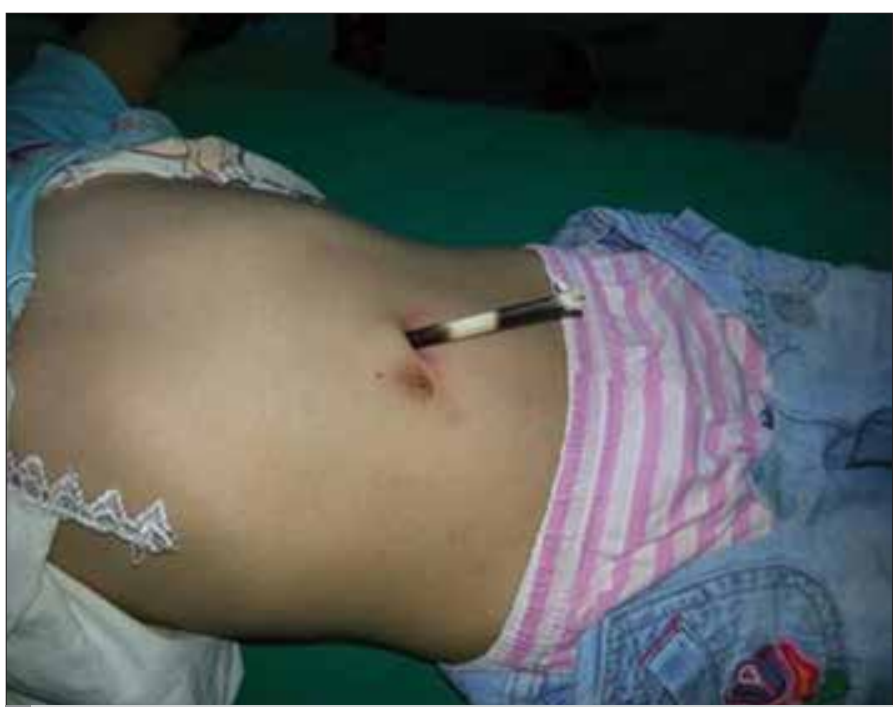

FIGURE 2. Porcupine quill penetrated the periumblical area of the second case

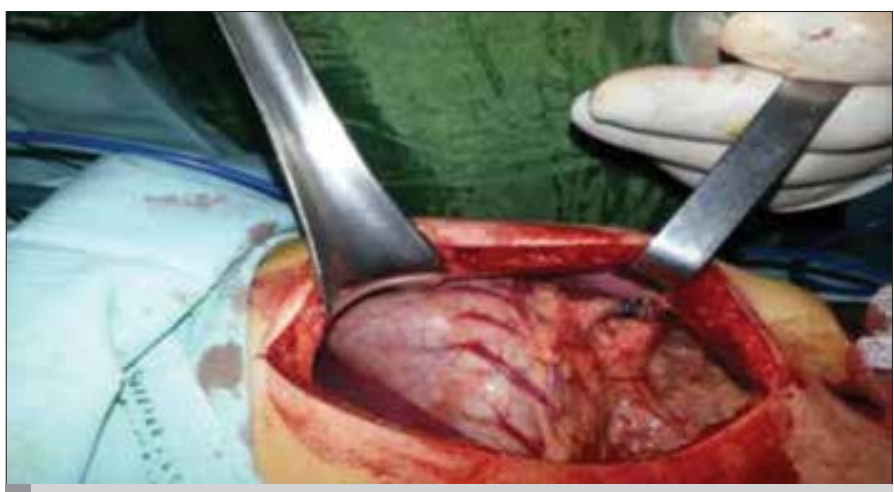

FIGURE 3. Porcupine quill penetrated the anterior and posterior gastric wall, and also caused a capsule defect on the second segment of the liver

every 6 hours and metronidazole IV 200 mg every 8 hours. Amylase and lipase levels were elevated after the fourth day of surgery, and the calculated amylase clearance level was higher than 10\%. Total parenteral nutrition was initiated because of pancreatitis. Control CT showed heterogeneity over the pancreatic area. Penetration of the quill was accepted as the cause of pancreatitis. At the postoperative fifth day the drainage, and at the twelfth day, nasogastric tube were removed. The patient started oral intake. Amylase and lipase levels returned to the normal level, and the patient was discharged. There was no complication in the follow up visits. Informed consent form was taken from both cases.

\section{Discussion}

Porcupinesare rodents, which are $60-90 \mathrm{~cm}$ tall and 5-16 kg weight. They have 3-8 mm thick, 15-35 cm long, sharp pointed dark colored tips, hallow spikes at their dorsum, shoulder and back of the neck. They also have 15-16 quills with 8-12 mm thickness in their tail. There are eight species in the genus Hystrix in the world, only two of which are found outside of Asia. The crested porcupine is widespread in Africa and Italy. Although it is favored in many regions as food, its conservation status is set at least concern (1). The porcupine species live especially in the Mediterranean and South-East regions in Turkey. They have no economical value, however some people hunt them for eating and children play with their spikes.

The porcupine quill resembles a spike and penetrates tissue with ease, however the penetrated spike is harder to remove than other foreign bodies. The surface of the spike is similar to fish flake and it is affixed to tissue when its removal is attempted. Therefore, it should be removed carefully opposite to the entrance direction. Otherwise the remaining keratinized tissue of the spike may lead to infection and foreign body reaction (5). Bin et al. (6) detected the Leishmania parasite on Hystrixindica spikes in their research. Therefore, antibiotic therapy should be considered against infection and infestation at the porcupine spike injury. Both of the cases had taken prophylactic antibiotics, and none of them had developed infection. Treatment for infestation was not considered.

The penetrated spike should be displaced with body movements due to its anatomical structure, which is similar to fish flake, and it might be found at another location than expected. JL Guevara et al. (7) reported that porcupine spike had migrated to the heart after penetrating the thorax.

Foreign bodies that penetrate the thorax and abdomen should not be removed. After hemostasis and bleeding control are achieved, the patient must undergo surgery for removal. The fixed objects could be cut over the skin to facilitate patient transportation (8).

Although there are many injuries reported in animals, only a small number of injuries have been reported for humans in the literature. Porcupine quill injuries resulting from altercations between porcupines and dogs occur frequently (9). 296 case series were published with dogs (4). Anderson et al. (10) reported jejunal perforation due to porcupine quill injury. One case was found about human injury in 1954. This case reported that an 87 year old was woman admitted to hospital with pain and difficulty swallowing after eating a hamburger, and a porcupine quill was found as the foreign body at the proximal esophagus (3). One case reported the hand injury of a 50 year old man after hitting a porcupine (4).One of our cases had gastric perforation and pancreas injury and the other had a foot injury. Both of them were children. One of them was playing with porcupine quills and was wounded by falling on it, and the other was wandering around the land when a porcupine attacked him. 


\section{Conclusion}

Wild animal injuries are rarely seen in emergency departments. Emergency physicians should have sufficient information about the treatment and complications of wild animal injuries because they could be life-threatening, as in our cases.

Informed Consent: Written informed consent was obtained from patients who participated in this study.

Peer-review: Externally peer-reviewed.

Author contributions: Concept - I.A., H.Ö.A.; Design - Ö.G.; Supervision - I.A.; Resource - I.A.; Materials - M.A.D.; Data Collection and/or Processing - I.T.; Analysis and/or Interpretation - I.A., Ö.G.; Literature Search - H.Ö.A.; Writing - I.A.; Critical Reviews - Ö.G.

Conflict of Interest: No conflict of interest was declared by the authors.

Financial Disclosure: The authors declared that this study has received no financial support.

\section{References}

1. Masseti M., Albarella U, De Grossi Mazzorin J. The crested porcupine, Hystrixcristata L., 1758, in Italy. Anthropozoologica 2010; 45 : 27-42. [CrossRef]
2. Johnson MD, Magnusson $\mathrm{KD}$, Shmon $\mathrm{CL}$, Waldner C. Porcupine quill injuries in dogs: a retrospective of 296 cases (1998-2002). Can Vet J 2006; 47: 677-82.

3. Harlowe HD. Unusual foreign body (porcupine quill) in the esophagus; case report. Laryngoscope 1954; 64: 691-2. [CrossRef]

4. Bernardes Filho F, Andrade JC, Queiroz DL, Lupi O. Brazilian porcupine quill injuries. J Eur Acad Dermatol Venereol 2016; 30: 530-2. [CrossRef]

5. Cho WK, Ankrum JA, Guo D, Chester SA, Yang SY, Kashyap A, et al. Microstructured barbs on the North American porcupine quill enable easy tissue penetration and difficult removal. Proc Natl Acad Sci U S A 2012; 109: 21289-94. [CrossRef]

6. Bin DS, Mostafa OM, Abdoon A, Al-Quraishy SA, Alqahtani AA. Isoenzyme electrophetic characterization of Leishmania major, the causative agent of zoonotic cutaneous Leishmaniasis in North and West Saudi Arabia. J Egypt Soc Parasitol 2010; 40: 465-78.

7. Guevara JL, Holmes ES, Reetz J, Holt DE. Porcupine quill migration in the thoracic cavity of a German shorthaired pointer. J Am Anim Hosp Assoc 2015; 51: 101-6. [CrossRef]

8. Tintinalli JE, Stapczynski JS. Tintinalli's Emergency Medicine: a comprehensive study guide. York: McGraw-Hill; Translation editor ÇeteY.NobelKitapevi 2013. p:1675.

9. Sauvé CP, Sereda NC, Sereda CW. Identification of an intra-cranial intra-axial porcupine quill foreign body with computed tomography in a canine patient. Can Vet J. 2012; 53:187-9.

10. Anderson SL, Panizzi L, Bracamonte J. Jejunal perforation due to porcupine quill ingestion in a horse. Can Vet J 2014; 55: 152-5. 